\title{
CURTAILING FERTILIZER SCARCITY AND CLIMATE CHANGE; AN APPRAISAL OF FACTORS AFFECTING ORGANIC MATERIALS USE OPTION IN NIGERIA'S AGRICULTURE
}

\author{
OMOTESHO, A.O., FAKAYODE, S.B. and TARIYA, Y. \\ DOI:http://dx.doi.org/10.4314/ejesm.v5i3.10
}

Received $24^{\text {th }}$ February 2012; accepted $29^{\text {th }}$ May 2012

\begin{abstract}
Global trends nowadays towards long term sustainable crop production is hinged on either supplementing the use of chemical fertilizers with organic materials or a complete use of organic materials. This is more so since substituting chemical fertilizers with organic materials reduces the risks of exposure to ailments that arise on account of synthetic compounds and increases farmers' gains via reduced soil erosion and carbon emissions and increased bio-diversity. The current study investigated organic materials use in Nigeria's agriculture. Specifically, the study examined availability and use of chemical fertilizers and organic materials substitutes and investigated factors affecting the use of organic materials in the Nigerian food sector. The study data were drawn from a survey of sixty-one farm households that used organic materials as major nutrients inputs or as supplement with chemical fertilizers for their cropping activities. The study area is Shira in Nigeria. Farmers in this area usually incorporate the use of organic materials in their agriculture. The descriptive statistics and regression analyses were used to analyse the study data. Results indicate that farmers in the study area source their chemical fertilizer inputs from the open market at an exorbitant price of $\$ 2000$ (US dollar \$13.8) per bag on average thereby using very low rates of chemical fertilizers. Organic materials used by farmers were sourced from cattle, goats, sheep and poultry droppings. The quantity of organic material used was $12,513.0 \mathrm{~kg}$ per hectare at a cost of $\$ 15,015.6$ (US dollar \$103.5). Major constraints in the use of organic materials by farmers include poor transport facilities and cutworm infestations of the organic materials. Factors revealed to influence the quantity of organic materials used by farmers were the cost of organic materials and the quantity of chemical fertilizers used by the farmers. The study therefore calls for stake-holders involvement in the establishment of blending plants for the production of organic materials, burning of organic materials before usage, and the need to enhance researches aimed at establishing optimal material mixtures and application rates for organic materials used in the Nigerian farming systems.
\end{abstract}

Key Words: farming systems, bio-diversity, carbon emissions, cut-worm infestation, sheep, goat, poultry

\section{Introduction}

Researchers in many part of the world have often times emphasized that one of the surest and perhaps most effective way of raising agricultural productivity is through the use of fertilizers, especially when it is combined with adequate water supply, improved seeds and good management practices (Abdulkarim,1994, Manyong, 2002). The fertilizer issue is more so, considering the current global food crisis. According to the Food and Agricultural Organisation Department of Agricultural Economics and Farm

Management, University of Ilorin. Nigeria

P.M.B 1515.

*Corresponding author's email: fakayode@unilorin.edu.ng projections (2006), seven African countries would need to produce up to $10 \%$ more food, twenty-seven countries between 10 and $25 \%$ and twenty countries in excess of $25 \%$ more food by 2015. Yields will need to be increased by significantly more than $1 \%$ per year for most crops to reach the production goals. Staple cereal crop yields will need to increase by approximately $30 \%$ for both rain-fed and irrigated crops and staple root crops by approximately $20 \%$ over the 15 year period to 2015. According to the report, this scenario 
when translated into fertilizer need accordingly predicted that the Africa requirements by 2015 for the increased yields and area expansions are an increase in total nutrients of $47 \%$ from 3.024 million tons to 4.48 million tons, equivalent to an average annual growth rate of $2.6 \%$. For Sub-Saharan Africa the projected increase is $63 \%$ or an annual growth rate of $3.3 \%$. The related effective demand for this volume of fertilizer nutrients will depend in particular on continuously increasing fertilizer use profitability through higher commodity prices received by farmers. However, the chemical fertilizer resource has usually been overstretched far beyond its availability in most of these countries. There has been little or no growth in fertilizer use for the past decade leading to nutrient mining and declining soil fertility.

In many of these countries, the prevalent high cost and scarcity of the chemical fertilizers has led farmers to rely on the use of organic materials such as waste, and animal droppings either as substitute to their chemical fertilizer stock or to complement their stock. Organic materials which refer to animal manure, ashes and plant compost contain nutrients for plant growth. The factors commending organic fertilizer as socially desirable are likely to become more significant overtime. Land application of animal manure increases soil organic matter and improves a number of soil properties including soil tilt, water holding capacity, oxygen content and soil fertility. It also reduces soil erosion, restores eroded croplands, improves solar heat absorption, increases water infiltration rates, reduces nutrients leaching and increases crop yields. In general, results of researches have indicated that manure is an available bioresource that should be utilized (Araji and Abdo, 2003).

In Nigeria, both the Federal Government and the World Bank have long emphasized that the high scarcity and low usage rates for chemical fertilizer has been the major factors responsible for the food problems in the country (Nema, 1983, Manyong, 2002). There is problem of scarcity and expensive fertilizer prices.
This in turn results in untimely applications of fertilizer and insufficient fertilizer use practices. Fertilizer depots are far away from farmers and the interference by middlemen and government officials in the distribution system forces farmers to buy from middlemen at exorbitant prices (Massam et al, 1987). These problems have led to poor farmers' access to chemical fertilizers and consequent low crop yields, which in turn translate to low receipts accruing to farmers.

Even in the face of these constraints, several efforts of farmers to either supplement chemical fertilizer use with organic materials or to completely use organic materials for their cropping purposes have not been successful, yet there is an urgent need to meet up with the fertilizer needs in the nation's agriculture. The need to either supplement chemical fertilizer usage or stop the use of chemical fertilizer in Nigeria's agriculture is more so as current trends the world over are tended towards discouraging the use of inorganic fertilizers, because of its associated risk of increasing Green House Gases (GHS) emissions. These emissions are responsible for devastating global warming and climate change effects.

The study attempts to answer the following research questions:

$>$ What is the nature of inorganic fertilizers use by farmers in Nigeria

$>$ What constraints limit the use of inorganic fertilizers?

$>$ What factors determine organic materials use by farmers?

\section{Objectives of the Study}

The broad objective of this study is to examine organic materials use in Nigeria's agriculture. Specifically, the study:

examined availability and use of chemical fertilizers and organic materials substitutes and

\& investigated factors affecting the use of organic materials in the Nigerian food sector. 


\section{Materials and Methods \\ Study Area}

This study was conducted in Shira Local Government Area (LGA) of Bauchi State. The study area lies along latitude $10^{\circ} 7^{\prime}$ North and longitude $9^{\circ} 49^{\prime}$ East, covering a geographical area of about 32,396 square kilometers. Shira LGA is bordered on the North by Azare, on the South, by Jamaare and on the East and West by Ningi and Giade Local Government Areas respectively (Abdulkarim, 1994). Shira has two seasons annually, namely the rainy and dry season. The rainy season occurs between June/July and September/October while the dry season starts in September/October and ends in May/June. April is the warmest month while mean temperatures ranges between $30.1^{\circ} \mathrm{C}-37.7^{\circ} \mathrm{C}$ (BSADP, 1995). Mean humidity is highest in August at $66.5 \%$ and lowest in February at $16.5 \%$ while annual rainfall ranges between 1016 - 1270mm (BSADP, 1996).

The vegetation in Shira is predominantly the open savanna woodland vegetation. Grasses in the area may reach up to $3.5 \mathrm{~m}$ or more in height. The soil texture in the area is characterized by stony and basement complex, the surface soil is free draining sandy soil loam and moderately deep (BSADP, 1994). The main economic activity in the Shira area is agriculture. Crops grown include cowpea, sorghum, groundnuts and millet. Farmers also rear livestock.

As regards the use of inorganic materials for agricultural purposes, Bauchi State is popular. The practice of inorganic material
LGAs include Ningi, Katagun, Zaki, Giade, Gamawa, Itas Gadau and Jama'ara and Shira. However, most inorganic material usage is widespread and prevalent in Shira LGA. This explains why Shira LGA was selected as the study area for this study. The selection decision is also based on the results of interviews with staff of the Bauchi State Agricultural Development Project (BSADP).

\section{Sampling Technique}

The study population comprised farm households across Shira LGA. The study sampling technique was a two stage sampling procedure. The first stage comprised random sample selection of three out of the thirteen communities popular for inorganic material usage in Shira LGA while the second stage involved the random selection of farm households across the three selected community. The farm households selected were those that use organic materials as major nutrient input in their farming activities.

These farm households were interviewed for the study. The sample design adopted for the study is as presented in Table 1. Though the study was set to interview hundred farm households, due to respondents' unwillingness to supply information and other data collection problems, a total of sixty one farmers were interviewed for the study. However, the study also sourced information from discussions with groups of farmers' interviews with other key informant including leaders of cooperatives and associations, Fulani herdsmen, and extension officers in the study area.

Table 1: Sample Design Adopted for Selecting Study Farm Households respondents

\begin{tabular}{lc}
\hline Communities & No. of Respondents \\
\hline Tsuddu & 10 \\
Tsafi & 28 \\
Anguwar Gabas & 23 \\
Total & 61 \\
\hline
\end{tabular}




\section{Data Analysis}

The data collected during the study were subjected to descriptive statistics and Ordinary Least Square (OLS) regression analyses. The descriptive statistical analysis comprised frequency, percentage and mean which were used to analyse the socio-economic characteristic of study respondents. The regression tools were used to identify determinant variables that affect respondent's use of inorganic materials for cropping purposes.

The regression model specified was expressed as

$$
Q=f\left(X_{1}, X_{2}, X_{3}, \ldots X_{9,}, \mu\right)
$$

Where variable $\mathrm{Q}$ is the quantity of organic material used. An average trailer load of organic material weighs 500 kilograms, $X_{1}=$ Age of farmer in years, $X_{2}=$ Household size, $X_{3}=$ Farm size in hectares, $X_{4}=$ Numbers of live stocks owned by respondent, $\mathrm{X}_{5}=$ Quantity of inorganic chemical fertilizer used in kilogram, $\mathrm{X}_{6}=$ Cost of organic materials in Naira, $\mathrm{X}_{7}=$ Cost of chemical fertilizer, $\mathrm{X}_{8}=$ On-farm labour in Man-days, $X_{9}=$ Off-farm labour in Man-days.and $\mu=$ error term.

The local unit for measuring farm size is the 'hantsin shanu' which connotes the land area covered by 2 working bulls for one day. On the average 1 hantsin shanu $=0.48$ hectares. Offfarm labour includes labour used for domestic activities like washing, cooking and petty trading.

\section{Results and Discussion \\ Socio-economic Profile of Respondents}

Table 2 presents the summary of the relevant socio-economic characteristics of study respondents. As farmers' age varies, they can become more or less risk averse in adopting a new agricultural technology. Age is significantly associated with the adoption of certain farm innovation. Young farmers are expected to be more flexible in their decision to adopt new practices that would improve their farm production and welfare. The mean age of the farmer respondents was 36 years (Table 2). This implies that farmers that used organic materials are young and agile youths who can encourage adoption of any viable technology like the use of organic material in the study area.

The time period that farmers are engaged in any activity to a large extent could give an indication of the extent of practical knowledge he or she has gained in the activity. Similarly, the number of years that farmers has been involves in farming business can therefore imply their extent of farming knowledge. As shown in Table 2, respondents have been involved in farming for about 18 years now implying that these farmers are well knowledgeable on farming activities. These farmers are also expected to be well acquainted with fertilizer use practices on their farms.

The household size of the farmer usually determines availability of family labour for use on household farms. Table 2 indicates that respondents possess large households that comprised 13 members on average. This is an incentive for the use of organic material in farming. This is so since farmers could have access to readily available family labour for their labour intensive organic material usage.

Table 2 Socio-economic Characteristic of Respondents

\begin{tabular}{llll}
\hline Characteristic & Frequency & Percentage $\%$ & Mean
\end{tabular}

Age of Household head

Farming Experience

Households size

Farming in hectare

Livestock ownership 


\begin{tabular}{|c|c|c|c|}
\hline Cattle & 31 & 50.8 & 1 \\
\hline Goat & 44 & 71.1 & 8 \\
\hline Sheep & 36 & 59.0 & 5 \\
\hline \multicolumn{4}{|c|}{ Poultry (chicken, Guinea fowl } \\
\hline \& duck) & 33 & 54.1 & 10 \\
\hline \multicolumn{4}{|l|}{ Crop \& Usage } \\
\hline \multicolumn{4}{|l|}{ Sorghum } \\
\hline Home consumption & 47 & 77.0 & \\
\hline Sales & 20 & 32.8 & \\
\hline Home \& sales & 20 & 32.8 & \\
\hline \multicolumn{4}{|l|}{ Millet } \\
\hline Home consumption & 45 & 88.5 & \\
\hline Sales & 20 & 32.8 & \\
\hline Home \& sales & 20 & 32.8 & \\
\hline \multicolumn{4}{|l|}{ Groundnuts } \\
\hline Home consumption & 23 & 37.7 & \\
\hline Sales & 18 & 29.5 & \\
\hline Home \& sales & 21 & 34.4 & \\
\hline \multicolumn{4}{|l|}{ Rice } \\
\hline Home consumption & 23 & 37.7 & \\
\hline Sales & 21 & 34.0 & \\
\hline Home \& sales & 10 & 16.4 & \\
\hline \multicolumn{4}{|l|}{ Cowpea } \\
\hline Home consumption & 36 & 59.0 & \\
\hline Sales & 29 & 47.5 & \\
\hline Home \& sales & 21 & 34.4 & \\
\hline
\end{tabular}

The quantity and type of fertilizers used by farmers depends on the extent of their farming activities in terms of their farm size. The average farm size cultivated by respondents was 0.97 hectare implying that respondents had small farm holdings. Hence they do not require large quantity of organic material for their farming activities. The organic manure utilized by respondents is predominantly sourced from their livestock faeces. The type and number of livestock raised by respondents will therefore determine the source and quantity of organic material available to the farmer for use. The various livestock owned by respondents include cattle, goats, sheep and poultry. The prominent livestock reared was goat while the mean number of cattle, goats, sheep and poultry were $1,8,5$ and 10 respectively (Table 2). Cattle were predominantly kept for traction. Most respondents were Muslims. This explains why they did not rear swine. On the overall, it is indicated that the number of animals reared by respondents were few; far below that that could supply organic materials for commercial farming purposes.

Also investigated was the type of crops cultivated by farmers and the purpose for which the crops were cultivated. In instances, where farmers produce for the market, the quantity of organic materials needed for cropping was usually higher. Farmers are willing to purchase more inputs if a cash income is anticipated (Mokokha et al, 2001). Major crops cultivated by the respondent were sorghum, millet, groundnuts, rice and cowpea. Sorghum, millet and rice were mainly cultivated for home consumption while cowpea was predominantly cultivated for sales (Table 2). The type and purpose of crop cultivation by respondent could probably explain why farmers may not require high levels of fertilizers for their farms. 


\section{Inorganic Fertilizer Use}

Table 3 presents the nature of inorganic fertilizer usage by respondents

Table 3 Inorganic Fertilizer Use Characteristics in Study Area.

\begin{tabular}{lcc}
\hline Characteristics & Frequency & Percentage \% \\
\hline Source of purchase & & \\
Open market & 52 & 85.0 \\
BASAC & 6 & 9.8 \\
Local Government Council & 4 & 6.6 \\
& & \\
Usage Constraints & 59 & 96.7 \\
High Purchase Price & 50 & 82.0 \\
Unavailable & 17 & 27.5 \\
Dry Spell & & \\
\hline
\end{tabular}

The Table shows that most respondents $(85.0 \%)$ obtained their chemical fertilizer from the open markets while only a handful of them (16.4\%) obtained theirs from government sources including the Bauchi State Agricultural Supply Company (BASAC) and the Agricultural Department at the Shira Local Government Council. The fact that most farmers obtained their fertilizer inputs from non-governmental outlets implies that government interventions in the sales of the commodity have not been effective. The findings agrees with Abdulkarim (1994) that the common constraints limiting the use of fertilizer were the high purchase price for the fertilizer commodity, scarcity even in situations where farmers had the where withal to purchase the commodity, poor rainfall and lack of needed brands of the commodity. The most common of the problems were the high purchase price and scarcity of the commodity. Sodangi (1981) and Massam et al (1987) also agreed with the findings in their studies on issues relating to fertilizer distribution and use in the study area, they found that the most common constraints to chemical fertilizer application were its high cost and unavailability of the commodity. They both attributed this to the fact that fertilizer depots were far from the study areas which invariably resulted in untimely delivery of fertilize supplies. They also attributed the problem to the interference of middlemen and government officials in the distribution system. This makes the commodities to reach farmers at exorbitant price.

Many of the respondents reported that the major fertilizer types used by respondents were Urea and Nitrogen Potassium Phosphate (NPK). Urea was mainly used for rice production while NPK was used for sorghum and millet production. Most of the respondents reported that they applied fertilizer only once during the production season using the branding fertilizer application method at $89.5 \mathrm{~kg}$ per hectare rates. Inorganic fertilizers were usually used as supplements to chemical fertilizers. Each $50 \mathrm{~kg}$ fertilizer bag sold at \#2000 (1 US Dollar equals \$150).

\section{Organic Material Usage}

Table 6 presents the organic material usage profiles by respondents in the study area. To a large extent, the constituent of organic materials determine their fertilizer potency. Most respondents explained that they used a combination of different materials to fertilizer their farms. About three-quarters of them were found to combined inorganic and organic fertilizers to fertilize their farms while only a quarter of them used solely organic materials to fertilize their farms (Table 4). The use of organic material will help agriculture and farmers alike in the country. According to the Soil Science Society of Nigeria (2008) 'all tiers of Government, using the Pub-private Partnership approach, should establish organic based fertilizer plants to complement inorganic 
fertilizers in order to improve soil fertility, ensure balanced plant nutrition and sound environmental management.

The most common organic material used by the respondents was cow dung. This was followed by goat droppings, sheep droppings, ashes and poultry droppings (Table 4). Most respondents also reported that they preferred goat droppings to all other organic materials because of its long time residual effects. Table 6 also indicates that the major means by which farmers transport their organic material from source to their farm was oxen driven trailers. Most of the oxen trailers were hired. The average distance of respondent farms from homes was about 1.8 kilometers. All respondents reported that they stored their organic material in heaps before transporting same to their farms. The heap storage technique involved spreading the organic materials at the frontage of residential buildings to decompose for about 1-3 months before it was conveyed to farm. About half of the respondents $(50.8 \%)$ burnt their organic material aside allowing the material to decompose. The burning activity involved the use of dried maize stalks from previous maize harvest, dry-hay and grasses to set ablaze the organic materials. This method reduces the materials into fine powder. Burning and decomposition helps prevent incidence of Argotic segetum (cut worm) infection and weeds infestation of the material.

All the respondents applied organic material to their farms by spreading it, before their land was ploughed. Farmers thereafter plant their crops. During each application exercise, materials were concentrated at areas where crop yields were observed to be low. It was also found that organic materials were mostly used for sorghum and millet based enterprises.

The average quantity of organic applied was $12180.32 \mathrm{~kg}$ per respondents while the usage rate per hectare was $12,5130 \mathrm{~kg}$ at a cost of $\$ 15,015.6$. Costs items included those of procurement, transportation and processing of the materials. Respondents also emphasized that whenever they used organic materials for their cropping activities, the fertility of their farmlands increased, thus leading to higher crop yields. However, the study respondents also encountered problems that limited their usage of organic materials. These included mainly that of poor and inadequate transportation and high incidences of cut worm infestation of materials. The cutworms become active and attack crops after the infected materials have been applied to the farms. Another prominent constraint was the high labour input requirement needed to prepare and applied organic materials. In this vein Mokokha et al, (2001) have indicated that farmers often reject organic materials because of its high labour demands and the variable quality of the product. Other problems highlighted by few were the incidence of low rainfall humidity (Table 4), which in turn limits essential decomposition necessary for good organic material potency. 
Table 4: Organic Materials Use Characteristics in Study Area

\begin{tabular}{|c|c|c|}
\hline Characteristics & Frequency & Percentage\% \\
\hline \multicolumn{3}{|l|}{ Source of materials } \\
\hline Personal & 45 & 73.8 \\
\hline Purchased & 16 & 26.2 \\
\hline Obtained Freely & 12 & 19.6 \\
\hline Corralling & 6 & 9.8 \\
\hline \multicolumn{3}{|l|}{ Type of Organic Materials } \\
\hline Cow dung & 39 & 63.9 \\
\hline Goat droppings & 33 & 54.0 \\
\hline Sheep dropping & 32 & 52.5 \\
\hline Ashes & 30 & 49.2 \\
\hline Poultry dropping & 11 & 18.0 \\
\hline \multicolumn{3}{|l|}{ Handling Activities } \\
\hline \multicolumn{3}{|l|}{ Transportation mode } \\
\hline Oxen Driven Trailers & 50 & 98.3 \\
\hline Head Pan & 1 & 1.6 \\
\hline \multicolumn{3}{|l|}{ Storage } \\
\hline In Heaps & 61 & 100.0 \\
\hline \multicolumn{3}{|l|}{ Processing } \\
\hline Burning & 31 & 50.8 \\
\hline No processing & 30 & 49.1 \\
\hline \multicolumn{3}{|l|}{ Usage Constraints } \\
\hline Cut worm incidence & 60 & 98.4 \\
\hline High labour & 59 & 96.7 \\
\hline Dry spell & 17 & 27.9 \\
\hline Weed infection & 10 & 16.4 \\
\hline Unavailability & 10 & 16.4 \\
\hline Slow decomposition & 9 & 14.8 \\
\hline Transportation problems & 60 & 98.4 \\
\hline
\end{tabular}

\section{Factors Affecting the Use of Organic Materials}

The lead regression model explaining factors that determine use of organic materials by respondents is the Double-log regression model. This is presented as equation (2)

$\log Y=1.663+-0.04971 \log X_{1}+1.040 \log$ $X_{2}+-0.159 \log X_{3}$

(1.833) $(-1.150)(12.612)^{*}(-1.774)^{*}$.

$\mathrm{R}^{2}=0.732$
Figures in bracket are $\mathrm{t}$ - values.

* means variable significant at 5\% level

The lead equation (2) was arrived at after different stepwise regressions were run on variable data collected. Only three of the variables; quantity of inorganic/chemical fertilizer used, cost of organic materials and off-farm labour remained as variables affecting the use of organic materials. All of these variables co-efficients have expected apriori signs. Only the cost of organic materials and 
quantity of chemical fertilizer used were indicated significant at $\mathrm{P}<0.005$. The quantity of off-farm labour was not indicated significant. The regression result therefore implies that the quantity of inorganic fertilizer and cost of organic material are significant factors determining usage of organic materials by respondents.

\section{Recommendations and Conclusion}

This study examined organic material use in Nigeria's agriculture. The study stems from the global quest to reduce Green House Gases (GHG) emissions due to inorganic/chemical fertilizer usage and the scarcity and high cost of inorganic fertilizers. Results from the study, reveals that farmers purchased their chemical fertilizer input mainly from open market sources at an exorbitant price of N2000 per bag on average. They could therefore apply very little chemical fertilizer at very low: below recommended, rates to their crops. The farmers were subsistence ones who owned cattle, goats, sheep and poultry. They therefore source their organic materials from these animal sources. The average cost of applying organic material was low. Average quantity of organic material used by farmers is $12.513 \mathrm{~kg}$ per hectare at an average cost of $\$ 15,015.6$. Major limitations to the use of organic material in farming were transportation and prevalence of cut worm infestation problems. Factors found to influence the use of organic materials were cost of organic materials and quantity of chemical fertilizer used by farmers.

Based on the study findings the study calls for the stimulation of initiatives, at establishing blending plants for the production of organic materials, for use in crop production in the study area. Private investors and farmers themselves can also collectively establish these plants. There is the urgent need to educate farmers on the environmental and climate friendliness of organic materials usage vis-àvis the environmental and climate hazards due to the use of chemical fertilizers. Farmers should also be educated on the advantages that accrue burning their organic materials before it is applied to their farms. Burning helps control the cut worm infestation of the materials. Farmers should also be encouraged to keep more animals especially poultry from which they can source enough organic materials for use on their farms.

Finally, relevant stake holders in the Nigeria food sub-sector should initiate researches at establishing the optional organic materials mix and application rates for the country's farming system. This invariably, if extended to farmers will encourage farmers to make better usage of available organic materials for their crops.

\section{References}

Abdulkarim, A (1994), Factor Affecting Demand And Fertilizer Use: A Case Study Of Bauchi

Araji, A.A and Abdo Z.O (2003), Optimal Utilization of Animal Manure on Croplands. Bulletin 829. University of Agriculture and Life Science.

Bauchi State Agricultural Supply Company (BASAC) Bulletins, Various Issues.

Food and Agricultural Organisation (FAO) (2002), Fertilizer Development in support of the Comprehensive Africa Agriculture Development Programme, $23^{\text {rd }}$ Africa Regional Conference, 2004. Africa Fertilizer Summit / IFDC / NEPAD.

Food and Agricultural Organisation (FAO) (2006), Terms of References for the Development of National Fertilizer Strategies in Africa Fertilizer Development. In Support of the Comprehensive Africa Agriculture Development Programme, $23^{\text {rd }}$ Africa Regional Conference, 2004.

Gaynor, B. (2009), Advantages and Disadvantages of Organic Farming. Available online at http://www.boozle .com. Accessed on $13^{\text {th }}$ July, 2009

International Federation of Organic Agriculture Movements (2006), Organic Agriculture Can Help Stabilize Global Climate Change. Organic Consumers Association. Available online at www.ifoam.org. Accessed on $10^{\text {th }}$ July, 2009

Kotschi, J. and Müller-Sämann, K. (2004), The Role of Organic Agriculture in Mitigating Climate Change. IFOAM. Bonn. 64. Available online at http://www.ifoam.org/orgagri/ClimateStudy_I FOAM. Accessed on 11th July,2009 
Local Government Area of Bauchi State. An Unpublished. B. Agriculture Technology Thesis. Abubakar Tafawa Balewa University. Nigeria.

Manyong V. Makinde,V.K.O and Ogungbile, A.G.O. (2002), Agricultural Transformation and Land

Use in the Cereal Based Systems of the Northern Guinea Savanna, Nigeria. In Vanlauwe, B. Diels, J. Sanginga, N, and Merckx, $\mathrm{R}$ (Eds). Integrated Plant Management in Sub-Saharan Africa: From Concept To Practice. 75-85. CAB International, Wallington-Ford OX10 8DE, UK. ISBN: 9-85199-576-4. Available Online at www.cabi-publishing.org Accessed on $13^{\text {th }}$ July, 2009.

Manyong, V.M., Makinde, N., Saginga, B.V and Diels, J. (2001), Fertilizer Use and Definitions of Farmer Domains for Impact Oriented Research in the Northern Guinea Savanna of Nigeria. Nutr Cyc Agroecosyt., 59(2): 129-141.

Massam, R .Y, Yuhana, R.and Baver, E.F.I.A (1987), The Impact of Fertilizer Application in
Nigeria. The Bauchi ADP Experience. Paper Presented at the National Fertilizer Seminar, Port-Harcourt, Nigeria held between 28-30 October, 1987.

Nema, D.M (1983), Economics of Fertilizer Distribution and Use in Gongola State . An Unpublished M.Sc Thesis. Ahmadu Bello University. Zaria. Nigeria

Nigeria. The Bauchi ADP Experience. Paper Presented at the National Fertilizer Seminar, Port-Harcourt, Nigeria held between 28-30 October, 1987.

Small Planet Institute (2008), Take a bit out of Climate Change. An Interview with Timothy LaSalle - Q\&A with Anna Lappé April 15th, 2008. Accessed at http://www.takeabite.cc/organic -farming-andcarbon-offsets/\# Accessed on $12^{\mathrm{TH}}$ July, 2009 Sodangi, S.I. (1981).Fertilizer Distribution and Use in Nigeria. Problems in the Development of increased Consumption. Paper Presented at the I.S.M.A. Conference, Rome, Italy 32p. 